\title{
Exploring Social Sciences Students' Perceptions on Information Literacy and the Use of Mobile Technologies in Higher Education
}

\section{Maria Pinto, Dora Sales, Rosaura Fernández-Pascual, and David Caballero-Mariscal}

\begin{abstract}
This study aims to examine information literacy (IL) and the use of mobile technologies in the educational sphere by a sample of social sciences undergraduate students $(\mathrm{N}=$ 1,390). The study used the MOBILE-APPS questionnaire, which is a scale for measuring students' perceptions regarding information literacy (both the institutional and as a personal dimension), the threshold concepts of the ACRL Framework and the use of ICT and mobile technologies in learning contexts. The survey was distributed to a sample of four universities and eight Social Sciences degrees in Spain. A descriptive, inferential, and multivariate study is performed, regarding age, course, gender, and degree. The results show that student perception is higher concerning the personal dimension of IL; most of the students are unaware of the threshold concepts of the ACRL Framework, and responses are very heterogeneous in relation to the use of ICT and mobile technologies. An MDS-clustering strategy regarding the diverse degrees that participate in the study is also provided, to grasp a disciplinary view. From the diagnosis developed in this research, some recommendations for teaching activity in IL as well as implications for academic libraries are provided.
\end{abstract}

\section{Introduction}

Two decades ago, when reflection on competency-based training began to boom in higher education research, the Organisation for Economic Co-operation and Development (OECD) ${ }^{1}$ asserted that key competencies are those necessary for personal development and fulfillment, active participation of citizenship, social inclusion, and employment. We live in an information society, surrounded by information and communication technologies, and the growing challenge is to learn to think critically about the resources and information we use and share. Information Literacy (IL) is increasingly important in all contexts of life, especially in the field of education. Thus, IL is undoubtedly one of the key competencies pointed out by

Maria Pinto is on the Faculty of Information Science at the University of Granada; email: mpinto@ugr.es. Dora Sales is on the Faculty of Human and Social Sciences at Jaume I University; email: dsales@trad.uji.es. Rosaura Fernández-Pascual is on the Faculty of Economic and Business Sciences at the University of Granada; email: rpascual@ugr.es. David Caballero-Mariscal is on the CMI La Inmaculada at the University of Granada; email: davidcaballero@ugr.es. (C2021 Maria Pinto, Dora Sales, Rosaura Fernández-Pascual, and David Caballero-Mariscal, Attribution-NonCommercial (https://creativecommons.org/licenses/by-nc/4.0/) CC BY-NC. 
the OECD and occupies an increasingly necessary place in our globalized and hyperconnected world. Johnston and Webber already proposed models for the information-literate university and the information-literate student, arguing that IL should be integrated into higher education curriculum. ${ }^{2}$ IL is increasingly necessary for all disciplines, all learning environments, and all educational levels. It always benefits those who get engaged with it, because IL promotes an empowerment and strengthening of the formative processes, and life in general. However, information society and its contexts are constantly changing, and IL is, therefore, an area in constant evolution. In the current educational context with a high usage of mobile technology, in any case it is essential to develop the informational and digital literacy of students. ${ }^{3}$

The ubiquity and immediacy of mobile devices has led to a change in undergraduate perceptions regarding the use of these devices in their learning processes in higher education. Hence, to adapt IL training to the reality in the classroom, there is a need to diagnose empirically the perceptions that students have. Thus, this study provides the view of students in various Social Sciences disciplines. The MOBILE-APPS questionnaire, Students' perception regarding the importance of using mobile technologies in the teaching-learning of information competencies (Mobile - Information - Literacy-Education-Attitudes - Perceptions-Prospectings - Students), which is a scale for measuring the students' perceptions regarding information literacy and the use of ICT and mobile technologies in learning contexts, has been used for this purpose.

Specifically, the following research objectives are addressed:

RO1. To discover the students' perception of what an information-literate university is and what fundamental skills an information-literate person should have.

RO2. To know the students' assessment of the IL threshold concepts defined in the Framework for Information Literacy for Higher Education proposed by ACRL. ${ }^{4}$

RO3. To comprehend the students' perceptions of the use of ICT, and especially of mobile technologies, in the educational context.

RO4. To identify patterns related to the perception of the students according to their degree of Social Sciences.

\section{Literature Review}

In the current educational context, IL is extensively understood from a metaliteracy view. ${ }^{5} \mathrm{In}$ this sense, the revised definition of CILIP Information Literacy Group is worth noting:

Information literacy is the ability to think critically and make balanced judgments about any information we find and use. It empowers us as citizens to reach and express informed views and to engage fully with society.... Information literacy is associated and overlaps with other literacies, including specifically digital literacy, academic literacy and media literacy. It is not a stand-alone concept, and is aligned with other areas of knowledge and understanding. ${ }^{6}$ 
Metaliteracy expands the coverage of traditional information skills (determine, access, locate, understand, produce, and use information) to hold the collaborative production and management of information in participative digital milieus. This approach requires a ceaseless adaptation to emerging technologies and a comprehension of the critical thinking required to engage in these contexts as producers, collaborators, and distributors. In recent years, in the field of higher education, together with the irruption of mobile technologies, the relevance of training in digital literacy has begun to be enhanced. Gallardo, Minelli de Oliveira, MarquésMolias, and Esteve-Mon review the range of concepts and approaches associated with digital literacy and its related terms, such as Information Literacy, Media Literacy, and Media and Information Literacy. ${ }^{7}$ Terminological diversity reveals that there is still no clear and uniform consensus, precisely because of the very dynamism of the digital environments. In this sense, the integrative perspectives are very interesting. ${ }^{8}$ In particular, Secker reflects on the possibility of considering "digital literacy" as a "bridging term" that allows the establishment of a holistic perspective to support the informational training of students, without forgetting that "digital is in many ways a distraction for teachers, who really need to focus on developing students' and their own critical abilities to handle information in all its guises effectively." 9

Taking into account the ever-changing informational environment, the ACRL proposed the thought-provoking Framework for Information Literacy for Higher Education. The Framework called for a renewed vision of IL as "an overarching set of abilities in which students are consumers and creators of information who can participate successfully in collaborative spaces. Metaliteracy, indeed, demands behavioral, affective, cognitive, and metacognitive engagement with the information ecosystem." ${ }^{10}$ Among other aspects, the Framework emphasizes the idea that learning is a dialogue with society and the relevant issues that shape our life contexts and that learners should be prepared to become informed citizens in a critical and continuous manner. Thus, in the specific field of higher education, the importance of the acquisition of information skills is key to the preparation of such critical citizenship. The Framework is articulated around six frames that are identified as essential threshold concepts for training and that are presented together with their respective associated knowledge practices and dispositions: Authority Is Constructed and Contextual; Information Creation as a Process; Information Has Value; Research as Inquiry; Scholarship as Conversation; and Searching as Strategic Exploration.

To date, the practical development of the Framework in the university context is still incipient, and it is essentially being developed in the United States. In view of the works that deal with the application of the Framework in higher education, it is relevant to highlight the contribution of Kuglitsch, who analyzes the tension between IL as a generalizable competency and as a competency applied to specific disciplines, with the aim of reflecting on teaching for transfer, using the Framework. ${ }^{11}$ In her opinion, the threshold concepts or frames of the Framework are widely applicable, but for this they have to be contextualized in disciplinary communities of practice. Also, Folk's qualitative study on the benefits of using students' own knowledge and previous experience in carrying out research assignments is based on the frames of the Framework, thus showing an example of its didactic application. ${ }^{12}$ The works by Scott and by Foster, Doyle, and Yukhymenko are of special interest. ${ }^{13}$ Scott offers an inspiring research that reflects on undergraduate students' perceptions on ACRL Framework IL threshold concepts, particularly on the transformative, integrative, and troublesome nature of the concepts. ${ }^{14}$ Her results show that students have interesting views on the concepts but tend to mix up application and theory. Foster, Doyle, and Yukhymenko developed the Student Perceptions of Information 
Literacy Skills (PILS) questionnaire to measure student self-perceptions of information skills using exclusively the six frames of the ACRL Framework to ask students about three variables related to each of the six frames, namely perceptions of skills, understanding, and feelings about each information frame, using the following scale: Novice, Advanced Novice, Emerging, Advanced Emerging, Developing, Advanced Developing, and Expert. ${ }^{15}$ A further study by Hofer, Lin Hanick, and Townsend offers a comprehensive exploration of how threshold concepts can be applied in IL training, identifying important elements and connections between each concept and relating theory to practical methods that can transform the way IL is taught. ${ }^{16}$ The authors explore in depth the didactic potential of threshold concepts for IL.

With regard to the massive influx of mobile devices and their use in the teaching and learning process and the acquisition of basic informational skills, it should be noted that they have developed especially during the current decade, when the use of mobile technologies has become commonplace in teaching-learning contexts, particularly in higher education. Walsh undertook an attitudinal study on information skills and the use of mobile devices. ${ }^{17}$ This pioneering analysis emphasizes the unstoppable presence of mobile technologies and the need for teachers and information professionals to adapt to this new reality for the benefit of the students. In a similar vein, Woodcock, Middleton, and Nortcliffe provided one of the first instruments that measure the inclusion of mobiles in the teaching-learning processes of higher education students and the perceptions about their use. ${ }^{18}$ Their conclusions recognized the growing relevance of mobiles' use and their incorporation for academic purposes as the main means of collaborative work. Havelka brings together the study of IL and mobile devices conceived as the only tool for accessing, processing, and analyzing information. ${ }^{19}$ Her study reviews the conceptualization of IL and mobile information literacy. This perspective directly and indirectly addresses the relationship between the acquisition of IL, the use of mobile devices for this purpose, and the growing development of applications for the teaching-learning process. In this direction, we can point out the role of mobile devices in the teaching-learning processes within the classroom and their relevance as instruments in the access, analysis, and selection of information in relation to libraries. In this sense, Yoon analyzes the level of incorporation of the mobile as an essential library tool. The agents involved - students, teachers, and librarians - show an increasing level of incorporation of devices and apps for this purpose. However, there are still discrepancies among the different groups. Hence the need for coordination and joint training is emphasized. ${ }^{20}$

In a similar vein, but from a qualitative perspective, Bosman and Strydom analyzed the growing advance of mobile technologies in university teaching contexts. ${ }^{21}$ Their research on mobile literacy focuses on the need to implement and develop mobile learning but delving into critical attitudes toward information.

Mullins addresses the role of apps in managing the library and accessing available sources and catalogues. From an empirical perspective and with a quantitative instrument, she studies the optimization of IL through mobile technologies. The research concludes that, despite their necessity and the advantages that apps bring, their use is limited and less adequate than expected. Despite the demand and the positive attitude, intergenerational and sector differences are noted (teachers, students, librarians). ${ }^{22}$

For Al-Emran, Elsherif, and Shaalan, generational differences in the use of mobile phones to access information, and as a fundamental tool for higher education, can be a conditioning factor for their management and inclusion in the classroom. ${ }^{23}$ If institutions do not proceed to make changes in the curriculum and implement methodologies that make their use viable 
in the university, a generation gap may open up between faculty and students. Along these lines, Hanbidge, Tin, and Sanderson developed an innovative experience of coordinated training action between the teaching staff and the library. Their joint and collaborative proposal improved results in terms of IL acquisition and development. The training and use of mobile apps also contributes to reducing the generation gap. ${ }^{24}$

Also, Hwang, Lai, Liang, Chu, and Tsai carried out a qualitative descriptive study of the use of mobiles in pre-university classrooms, especially for access to and processing of information. ${ }^{25}$ They also analyzed the acquisition and development of critical thinking and communication skills necessary for students in their undergraduate stage. As these authors conclude, mobiles and applications are the indispensable means of relationship among peers. But they should change their perspective to understand that the scope of these new tools affects not only informal settings but also formal education.

\section{Methodology}

\section{The Sample}

Participants are social sciences undergraduates of four Spanish universities (University of Granada, University Jaume I of Castellón, University of Murcia, and Complutense University of Madrid) from eight degrees: Audiovisual Communication, Information Science, Business Management and Administration, Economy, Education, Journalism, Pedagogy, and Tourism. These social science degrees were chosen due to their representativeness in terms of the relevance of IL for the education of their students and their future working life. At the same time, it was considered that these degrees are a diverse cluster that could offer an enriched perspective of the results.

Nearly all (98.5\%) of the participants study on-site. The demographic characteristics of the sample are shown in table 1.

\begin{tabular}{|c|c|c|c|}
\hline \multicolumn{4}{|c|}{$\begin{array}{c}\text { TABLE } 1 \\
\text { Demographic Characteristics of the Sample }\end{array}$} \\
\hline \multirow[t]{10}{*}{ Participants } & Degree & Frequency & $\%$ \\
\hline & Audiovisual Communication & 100 & 7.2 \\
\hline & Business Management and Administration & 189 & 13.6 \\
\hline & Economy & 128 & 9.2 \\
\hline & Education & 451 & 32.4 \\
\hline & Information Science & 97 & 7 \\
\hline & Journalism & 117 & 8.4 \\
\hline & Pedagogy & 144 & 10.4 \\
\hline & Tourism & 164 & 11.8 \\
\hline & Total & 1,390 & $100 \%$ \\
\hline \multirow[t]{5}{*}{ Level/Course } & & Frequency & $\%$ \\
\hline & First & 152 & 11 \\
\hline & Second & 72 & 5 \\
\hline & Third & 624 & 45 \\
\hline & Fourth & 542 & 39 \\
\hline Age & Range $18-40$ years & \multicolumn{2}{|l|}{ Mean 21.7} \\
\hline Gender & Female $68.9 \%$ & \multicolumn{2}{|c|}{ Gender index 2.21} \\
\hline
\end{tabular}


Besides the degree in Information Science, it is important to put forward that IL is addressed explicitly only in a single course in the Audiovisual Communication and Journalism degrees and, regretfully, in none in the Business Management and Administration, Tourism, Economy, Education, and Pedagogy degrees. In these last degrees, however, students are made to see that it is important to learn how to search, contrast, and manage information in order to carry out academic tasks since it is part of diverse assignments required in the subjects they are studying. All students are familiar with what it means to study and live in today's information society, and this research aims to get closer to their perceptions.

\section{MOBILE-APPS Questionnaire}

The questionnaire (see appendix) has been previously validated, ${ }^{26}$ and this study offers the first results of its use. MOBILE-APPS questionnaire is an attitudinal scale composed of $22 \mathrm{IL}$ items clustered in the following four dimensions:

D1. Information-literate university: It is made up of five items and focuses on analyzing students' perceptions of what an information-literate university is, reflecting on its role in higher education and its relevance in promoting information access, analysis, and critical treatment.

D2. Information-literate person: It includes six basic information skills that are developed at a personal level, focusing on access, knowledge, critical analysis of information sources, production, and dissemination.

D3. Perception on IL threshold concepts: It gathers the six threshold concepts included in the ACRL Framework: authority is constructed/contextual, information creation as a process, information has value, research as inquiry, scholarship as conversation, and searching as strategic exploration. The wording of the concepts was revised with the aim of facilitating the students' understanding. Most of the students in the sample do not explicitly know the Framework, but we consider that it is fruitful to analyze their perception of the threshold concepts, with which they can interact using critical reflection, to contribute to this initial diagnosis.

D4. ICT, Mobile technologies (MobT), and students: It is made up of five items related to the impact (positive or negative) of ICTs, especially mobile devices, on student learning processes.

\section{Data Collection}

A stratified sample design has been carried out that guarantees the representation of the information obtained and allows inferences to be made with sufficient consistency. A proportionate stratified probability sample was considered (with proportional allocation), with three strata: university, degree, and academic year, according to the total number of students enrolled in each stratum.

The sample is made up of students enrolled for the academic year 2018-2019. The data collection was carried out between the months of October and February. The survey was preferably completed online, either by computer or by mobile phone (using the QR code), and the support of the teaching staff of the degrees involved was available. In a few cases $(9 \%$ of the sample), when the teaching staff advised this method, the questionnaire was administered in the classroom and on paper by a researcher of the work team trained for this purpose. Subsequently, the information was entered into the general database. A total of 1,390 valid surveys were obtained. See table 2 for technical details of the sample collection. 


\begin{tabular}{|l|l|}
\hline \multicolumn{2}{|c|}{$\begin{array}{c}\text { TABLE } 2 \\
\text { Sample: Technical Data }\end{array}$} \\
\hline Design & Stratified probabilistic sampling by degree and university \\
\hline Academic Year & $2018-2019$ \\
\hline Collection Period & October 2018-February 2019 \\
\hline Methodology & Online: via computer or mobile phones (QR code) \\
\hline \multirow{2}{*}{$\begin{array}{l}\text { Link to MOBILE-APPS } \\
\text { Questionnaire }\end{array}$} & Original Spanish: \\
\cline { 2 - 2 } & http://infocompetencias.com/cuestionarios/estudiantes/ \\
\cline { 2 - 2 } & English translation: \\
\cline { 2 - 2 } & http://infocompetencias.com/cuestionarios/estudiantesEN/ \\
\cline { 2 - 2 } & \\
\hline No. of Valid Surveys & 1,390 \\
\hline
\end{tabular}

The scale's reliability of the questionnaire was tested, calculating the Cronbach's alpha coefficient, overall and for each dimension of MOBILE-APPS. All the values exceed the recommended minimum of 0.7 , which indicates a credible level of reliability and internal consistency, ${ }^{27}$ except for the dimension D4 (ICT, MobT, and students) (see table 3).

\begin{tabular}{|l|l|l|}
\hline \multicolumn{3}{|c|}{ Reliability Estimates for the Student's Perception Questionnaire } \\
\hline Dimension & Cronbach's alpha & Cronbach's alpha if item deleted \\
\hline D1: Infolit University & 0.725 & $0.653-0.778^{*}$ \\
\hline D2: Infolit Person & 0.805 & $0.760-0.795$ \\
\hline D3: ACRL Framework Threshold Concepts & 0.73 & $0.655-0.744^{* *}$ \\
\hline D4: ICT, MobT, and Students & 0.691 & $0.627-0.668$ \\
\hline Global & 0.792 & $0.776-0.803^{* * *}$ \\
\hline $\begin{array}{l}\text { *The scale improves if item } 5 \text { is removed. } \\
\text { **The scale improves if item 12 is removed. } \\
\text { ***The scale improves if items } 18 \text { and 19 are removed. }\end{array}$ \\
\hline
\end{tabular}

Data processing was performed using IBM SPSS Statistics 22 software. Descriptive and multivariate techniques are considered. As data are not normally distributed, nonparametric methods are taken into account. Finally, a cluster analysis has been carried out and a multidimensional scaling technique (MDS) has been applied to provide a map that displays the position of the degrees, the similarities between them, and the detected clusters in relation to the four dimensions addressed by the MOBILE-APPS questionnaire: the institutional (D1) and personal (D2) view on IL, the threshold concepts of the ACRL Framework (D3), and the use of technologies, especially mobile ones (D4).

\section{Results}

A general overview of the results obtained when applying MOBILE-APPS questionnaire is offered, taking into account its four dimensions (see table 4). It is observed that the measures of central tendency (mean and median) present similar average values just under 4 points on a 1 to 5 scale, and variable dispersion is perceived in the responses. 


\begin{tabular}{|l|c|c|c|c|c|}
\hline \multicolumn{7}{|c|}{ TABLE 4 } \\
& $\begin{array}{l}\text { G1-Infolit } \\
\text { University }\end{array}$ & $\begin{array}{l}\text { D2-Infolit } \\
\text { Person }\end{array}$ & $\begin{array}{l}\text { D3-ACRL Framework } \\
\text { Threshold Concepts }\end{array}$ & $\begin{array}{l}\text { D4- ICT, MobT, and } \\
\text { Students Positive } \\
\text { Impact }\end{array}$ & $\begin{array}{l}\text { D4- ICT, MobT, and } \\
\text { Students Negative } \\
\text { Impact }\end{array}$ \\
\hline Mean & 3.83 & 4 & 3.98 & 3.91 & 3.41 \\
\hline Median & 3.8 & 4 & 3.83 & 4 & 3.8 \\
\hline Std. Dev. & 0.9 & 0.86 & 0.85 & 1.02 & 1.25 \\
\hline
\end{tabular}

\section{Perceptions on Information-Literate University and Information-Literate Person}

In relation to the scores declared in the dimensions D1: Infolit University and D2: Infolit Person, the results granted to three items of $\mathrm{D} 2$ stand out: 7-Understands and uses relevant and quality information sources, 8-Uses varied information resources efficiently and effectively, and 9-Evaluates information sources in an analytical and critical manner, with average levels exceeding 4 points (see table 5). Regarding the dispersion of the scores, greater homogeneity is observed in the perception of D1 item 4-Makes the teaching-learning process easier, and D2 items 6-Knows how to identify their information needs, 7-Understands and uses relevant and quality information sources, and 8-Uses varied information resources efficiently and effectively.

\begin{tabular}{|l|c|c|}
\hline \multicolumn{2}{|c|}{ TABLE 5 } \\
\multicolumn{1}{|c|}{ Descriptive Results MOBILE-APPS by Item, D1 and D2 } & Mean & Std. Dev. \\
\hline \multicolumn{1}{|c|}{ D1: The informationally literate university... } & \\
\hline \multicolumn{1}{|c|}{ D2: An informationally literate person is one who... } & 3.89 & 0.866 \\
\hline 1. Is the future of higher education & 3.72 & 0.898 \\
\hline 2. Promotes critical and reflective thinking in the education community & 3.93 & 0.884 \\
\hline 3. Fosters lifelong learning & 4 & 0.856 \\
\hline 4. Makes the teaching-learning process easier & 3.62 & 1.045 \\
\hline $\begin{array}{l}\text { 5. Assumes that teaching will be of an increasingly ubiquitous nature (online } \\
\text { education and blended learning) }\end{array}$ & & \\
\hline \multicolumn{1}{|c|}{. } & 3.9 & 0.82 \\
\hline 6. Knows how to identify his/her information needs & 4.13 & 0.831 \\
\hline 7. Understands and uses relevant and quality information sources & 4.22 & 0.805 \\
\hline $\begin{array}{l}\text { 8. Uses varied information resources (websites, databases, eBooks, books, academic } \\
\text { articles, and other resources) efficiently and effectively }\end{array}$ & 4.07 & 0.888 \\
\hline 9. Evaluates information sources in an analytical and critical manner & 3.78 & 0.949 \\
\hline 10. Properly cites the information sources used & 3.93 & 0.875 \\
\hline 11. Knows how to disseminate information in a rigorous and appropriate manner
\end{tabular}

In what follows, we study the influence of course, university, age, and gender. There are no significant differences according to the course or the university (Kruskal-Wallis, $p>0.05$ ). Nonetheless, there are statistically significant differences in relation to age in item 3 -Fosters lifelong learning, in which participants over 30 years of age show an average score of around 3.5 points, a much lower score than the values declared in this item by young people under 30 . 
With regard to gender, there are clear statistically significant differences in all items of D2: Infolit Person dimension, in which female students state that they agree more than male students (U-Mann Whitney, $p<0.05$ ). Conversely, there are no significant gender differences in the perception of what an information-literate university should be (D1: Infolit University).

\section{Perceptions on ACRL Framework Threshold Concepts}

In relation to the scores declared in the third dimension of the questionnaire, the students' perception of IL threshold concepts (see table 6), the ratings given to items 13-Creating information is a process and 14-Information has value, with average levels exceeding 4 points and low dispersion, stand out. The low valuation of item 12-Authority is constructed and contextual is also evident, with a mean of 3.40 associated to the greater dispersion of the dimension (std. dev. 0.93).

\begin{tabular}{|l|c|c|}
\hline \multicolumn{3}{|c|}{ TABLE 6 } \\
\hline \multicolumn{1}{|c|}{ Descriptive Results MOBILE-APPS by Item, D3 } \\
\hline \multicolumn{1}{|c|}{ D3: ACRL Framework Threshold Concepts } & Mean & Std. Dev. \\
\hline 12. Authority is constructed and contextual & & \\
\hline 13. Creating information is a process & 3.4 & 0.933 \\
\hline 14. Information has value & 4.11 & 0.791 \\
\hline 15. Research is a process of questioning & 4.53 & 0.687 \\
\hline 16. Learning is a dialogue & 3.84 & 0.902 \\
\hline 17. The search for information is a strategic exploration & 3.97 & 0.914 \\
\hline
\end{tabular}

There are statistically significant differences according to age in item 14-The information has value (it is detected that the degree of agreement increases with age). There are no differences by course or university. There are also no gender differences in this dimension, so males and females perceive the IL threshold concepts in a similar way.

\section{Perceptions on ICT, MobT, and Students}

Finally, in relation to the scores declared in the ICT and mobile technologies dimension (D4, see table 7), the rating of item 18-I usually take notes or search for information on mobile devices stands out, with an average score of 4.31 points.

D4 is the dimension with the greatest heterogeneity. This result is possibly due to the different level of incorporation of ICT in the teaching of the degrees analyzed, as evidenced in the following section.

Statistically significant differences are also detected according to age, in items 21 - The use of ICTs lowers the importance I give to properly citing sources and 22-Mobile devices have contributed toward my being more distracted in class. In these items, there is a lower degree of agreement with increasing age; that is to say, older students seem to use ICTs more effectively and perceive that they do not generate too much negative impact on their learning.

There are no differences by course or university. As for gender, there are clear differences in this dimension (D4: ICT, MobT, and students), in which male students score lower in items 18, 19 and 20 (positive impact) and higher in items 21 and 22 (negative impact): in other words, it seems that they use ICT worse. 


\begin{tabular}{|l|c|c|}
\hline \multicolumn{2}{|c|}{ TABLE 7 } \\
\hline \multicolumn{1}{|c|}{ Descriptive Results MOBILE-APPS by Item, D4 } & Mean & Std. Dev. \\
\hline \multicolumn{1}{|c|}{ D4: The use of ICTs and mobile settings in the learning process } & & \\
\hline $\begin{array}{l}\text { 18. I usually take notes or search for information on mobile devices (laptops, tablets, } \\
\text { or smartphones) }\end{array}$ & 4.35 & 0.92 \\
\hline $\begin{array}{l}\text { 19. I believe that I am able to access all the information I need using ICTs and mobile } \\
\text { devices }\end{array}$ & 3.97 & 0.963 \\
\hline $\begin{array}{l}\text { 20. I believe that instant access to information improves my critical thinking skills } \\
\text { when selecting verified information and documents }\end{array}$ & 3.42 & 1.171 \\
\hline 21. The use of ICTs lowers the importance I give to properly citing sources & 3.14 & 1.230 \\
\hline 22. Mobile devices have contributed toward my being more distracted in class & 3.68 & 1.263 \\
\hline
\end{tabular}

\section{Discipline-Based Perceptions}

The fourth objective of this study is addressed in two parts. First, the differences between degrees with nonparametric techniques are examined. Then, the positioning (by means of cluster and MDS), showing their pairwise similarities and the identified groups, is studied.

Thus, first, the overall perception declared by students on the four dimensions of the MOBILE-APPS questionnaire is compared and classified according to their degree. Average values per dimension range from 3.52 to 4.20 on a scale of 1-5 (see table 8).

\begin{tabular}{|l|c|c|c|c|c|}
\hline \multicolumn{7}{|c|}{ TABLE 8 } \\
\hline & $\begin{array}{l}\text { Mean Values by Dimension and Degree } \\
\text { University }\end{array}$ & $\begin{array}{l}\text { D2-Infolit } \\
\text { Person }\end{array}$ & $\begin{array}{l}\text { D3-ACRL } \\
\text { Framework } \\
\text { Threshold } \\
\text { Concepts }\end{array}$ & $\begin{array}{l}\text { D4- ICT, MobT } \\
\text { and Students } \\
\text { positive } \\
\text { impact }\end{array}$ & $\begin{array}{l}\text { D4- ICT, MobT } \\
\text { and Students } \\
\text { negative } \\
\text { impact }\end{array}$ \\
\hline Audiovisual Communication & 3.71 & 3.95 & 3.96 & 3.7 & 3.22 \\
\hline $\begin{array}{l}\text { Business Management and } \\
\text { Administration }\end{array}$ & 3.74 & 3.9 & 3.66 & 3.86 & 3.48 \\
\hline Economy & 3.91 & 3.98 & 3.9 & 3.94 & 3.35 \\
\hline Education & 3.83 & 4.03 & 3.89 & 3.97 & 3.42 \\
\hline Information Science & 3.72 & 4.2 & 3.85 & 3.87 & 3.15 \\
\hline Journalism & 3.63 & 4.02 & 3.85 & 3.81 & 3.29 \\
\hline Pedagogy & 3.77 & 3.97 & 3.92 & 3.81 & 3.18 \\
\hline Tourism & 3.7 & 3.75 & 3.72 & 3.87 & 3.54 \\
\hline
\end{tabular}

The degree in Information Science is the one that values the personal dimension of IL (D2) the most. Economy heightens the institutional dimension of IL (D1). Audiovisual Communication values the $A C R L$ Framework threshold concepts (D3) to the greatest extent. Economics and Education seem to be the degrees that use ICT and mobile devices in the teaching process in a better way (D4), since they score high on items 18, 19, and 20. On the other hand, Business Management and Administration and Tourism score high at 21 and 22: that is, they perceive more the negative impact of ICT. In this last sense, the degree that declares the lowest score is Information Science. 
Significant differences are found between the degrees analyzed in the global values declared in each dimension (Kruskal-Wallis, $p<0.05) .{ }^{28}$ To examine these differences in depth, the degrees are compared in pairs (see table 9 ).

\begin{tabular}{|c|c|c|c|c|c|c|c|c|}
\hline \multicolumn{9}{|c|}{$\begin{array}{c}\text { TABLE } 9 \\
\text { Significant Differences between Degrees, } p<0.05\end{array}$} \\
\hline & $\begin{array}{c}\text { Audiovisual } \\
\text { Communication }\end{array}$ & $\begin{array}{l}\text { Business and } \\
\text { Administration }\end{array}$ & Economy & Education & \begin{tabular}{|c|} 
Information \\
Science
\end{tabular} & Journalism & Pedagogy & Tourism \\
\hline \multicolumn{9}{|l|}{$\begin{array}{l}\text { Audiovisual } \\
\text { Communication }\end{array}$} \\
\hline $\begin{array}{l}\text { Business and } \\
\text { Administration }\end{array}$ & D4 & & & & & & & \\
\hline \multicolumn{9}{|l|}{ Economy } \\
\hline Education & D4 & D3 & & & & & & \\
\hline $\begin{array}{l}\text { Information } \\
\text { Science }\end{array}$ & & D1 D2 & D2 & D1 D4 & & & & \\
\hline Journalism & & D3 & D1 & & & & & \\
\hline Pedagogy & & & & D4 & D2 & & & \\
\hline Tourism & D3 & & D1 & D2D3 & D1 D3 & D2 & D3 & \\
\hline \multicolumn{9}{|c|}{$\begin{array}{l}\text { D1: Infolit University (red). } \\
\text { D2: Infolit Person (blue). } \\
\text { D3: ACRL Framework Threshold Concepts (green). } \\
\text { D4: ICT, MobT and Students (black). }\end{array}$} \\
\hline
\end{tabular}

Finally, to provide the grouping that reveals the relationships between the degrees, it is interesting to apply a cluster analysis. ${ }^{29}$ Cluster analysis is a statistical method for classification, used in this study as a way of determining homogeneous groups of degrees based on the similarity of responses regarding declared perceptions. ${ }^{30}$

To externally validate the resulting classification, ${ }^{31}$ the multidimensional scaling technique (MDS) has been applied. ${ }^{32}$ This technique makes it possible to visualize the relationships found after the cluster analysis and manually provide a map of relations that represents the similarities found, allowing some patterns of behavior to be distinguished. MDS allows the 22 analyzed variables (MOBILE-APPS questionnaire) to be represented in a space of low dimension, normally $2 \mathrm{D}$, transforming the perception of each degree in its corresponding spatial location, where the distance between them represents the similarity (see figure 1).

The results make it possible to identify four essential groupings of degrees: the first is made up of Business Management and Administration and Tourism; the second group is made up of Economy and Education degrees. The third group includes Audiovisual Communication, Pedagogy, and Journalism. Finally, Information Science is isolated from the other degrees.

\section{Discussion}

It is observed that there is a gap between the results of the institutional and the personal perceptions obtained according to dimensions D1 (university) and D2 (person) of the MOBILE-APPS questionnaire. That is, students perceive the importance of IL more for their own learning needs than as part of what the university institution itself has to promote. It also indicates that 


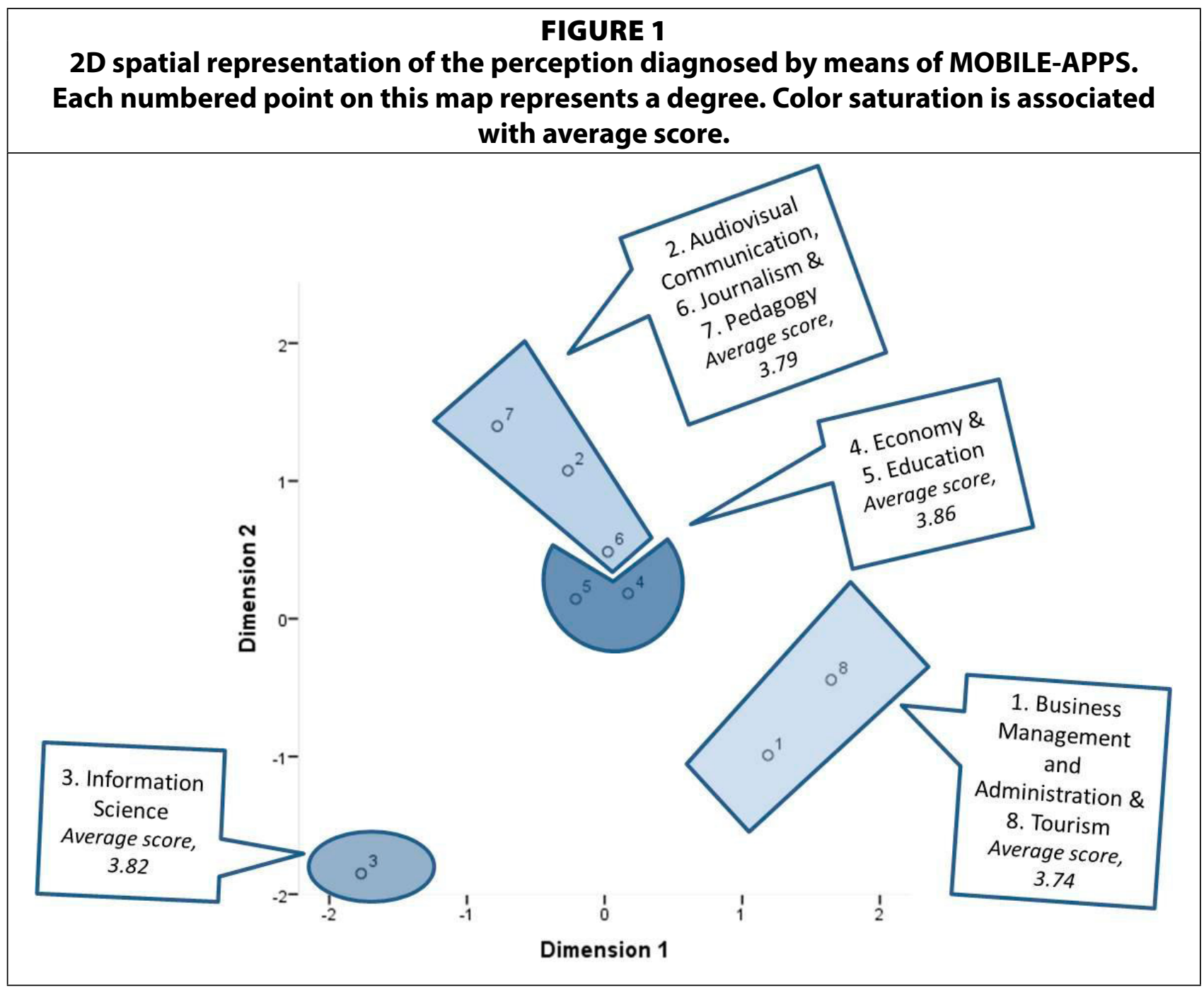

female students are the ones who have the greatest perception about the personal dimension of IL. That is, female students are more aware of the importance of IL on an individual level, as something each person needs and strives for personally.

On the threshold concepts of the ACRL Framework (D3), it must be taken into account that most university students are not familiar with the new dimensions of IL, as well as key concepts that define 21st-century IL, including those of the Framework. In the Spanish university system, most undergraduate degrees have no information literacy course in the curriculum despite the fact that their academic training and subsequent professional projection increasingly requires it. This lack of knowledge explains the low scores recorded in this dimension in general, without significant differences in any variable (including age, course, gender).

In relation to D4 (ICT, MobT, and students), a high heterogeneity is detected in this dimension, which highlights the different level of incorporation of ICT in education. Older age and female gender seem to be factors related to lower negative impact of ICTs on learning.

It is evident that there are significant differences between Social Science degrees. From figure 1 and table 8 , the following aspects can be noticed:

With regard to the perception of what students "understand" of an information literate university (D1), it is important to highlight the above average values of students in Economics 


\begin{tabular}{|c|c|c|c|}
\hline \multicolumn{4}{|c|}{$\begin{array}{c}\text { TABLE } 10 \\
\text { Degrees' Position Regarding the MOBILE-APPS Dimensions }\end{array}$} \\
\hline \multirow[b]{2}{*}{ Dimension } & \multicolumn{3}{|l|}{ Position } \\
\hline & Outstanding & Medium & Low \\
\hline D1-Infolit University & $\begin{array}{l}\text { Economics and } \\
\text { Education }\end{array}$ & Pedagogy & The rest of degrees \\
\hline D2-Infolit Person & Information Science & $\begin{array}{l}\text { Audiovisual } \\
\text { Communication, } \\
\text { Journalism, and } \\
\text { Pedagogy }\end{array}$ & $\begin{array}{l}\text { Business Management } \\
\text { and Administration and } \\
\text { Tourism }\end{array}$ \\
\hline $\begin{array}{l}\text { D3-ACRL Framework } \\
\text { Threshold Concepts }\end{array}$ & $\begin{array}{l}\text { Audiovisual } \\
\text { Communication and } \\
\text { Pedagogy }\end{array}$ & Information Science & $\begin{array}{l}\text { Business Management } \\
\text { and Administration and } \\
\text { Tourism }\end{array}$ \\
\hline $\begin{array}{l}\text { D4- ICT, MobT, and } \\
\text { Students Positive Impact }\end{array}$ & $\begin{array}{l}\text { Economics and } \\
\text { Education }\end{array}$ & $\begin{array}{l}\text { Business } \\
\text { Management and } \\
\text { Administration and } \\
\text { Tourism }\end{array}$ & $\begin{array}{l}\text { Audiovisual } \\
\text { Communication, } \\
\text { Journalism, and } \\
\text { Pedagogy }\end{array}$ \\
\hline $\begin{array}{l}\text { D4- ICT, MobT, and } \\
\text { Students Negative Impact }\end{array}$ & $\begin{array}{l}\text { Information } \\
\text { Science, Audiovisual } \\
\text { Communication, } \\
\text { Journalism, and } \\
\text { Pedagogy }\end{array}$ & $\begin{array}{l}\text { Economics and } \\
\text { Education }\end{array}$ & $\begin{array}{l}\text { Business Management } \\
\text { and Administration and } \\
\text { Tourism }\end{array}$ \\
\hline
\end{tabular}

and in Education, while the rest of the degrees show heterogeneity of students' perception. Likewise, it is observed that there are discrepancies between the degrees in the perception of what the students "understand" of an information literate person (D2). In this respect, and although it is not surprising, the students in Information Science demonstrate a greater awareness of almost all the items. Regarding D3 (ACRL Framework threshold concepts), there are also differences in perception between the degrees. Audiovisual Communication and Pedagogy claim to be more in agreement with all the items related to the ACRL Framework threshold concepts.

In relation to the $\mathrm{D} 4$ dimension (ICT, MobT, and students), the different level of incorporation of ICT in the teaching of the Social Sciences degrees analyzed is confirmed. Economics and Education seem to be the degrees that use technologies and mobile devices in the learning process in a better way. In the case of Education, it should be noted that the curricula incorporate two compulsory subjects devoted to the use of technological resources and educational technologies. For their part, students in Economics are familiar with specific software, official databases, and online apps and platforms accessing sources relevant to their discipline, such as stock markets.

The use of mobile devices may lead to a greater willingness to use technology, but it also leads to a dependence on devices for access to information. In other words, because of the familiarity with which students use mobiles, they may be inclined to integrate them into their academic life; but, at the same time, this may give them a feeling that the mobile is enough to access the information they need, and they may trust these devices too much and lose sight of the need to reflect deeply and turn to other resources, such as the library. In fact, library professionals could help them integrate the mobile devices they already use, really taking 
into account the training possibilities they offer, mainly through the knowledge and use of apps and other mobile training resources.

In addition, the ubiquity and immediacy of mobile phones in classrooms can lead to a greater distraction and tendency to relax attitudes toward the access, management, and processing of information. ${ }^{33}$ This is also diagnosed in the present research, in the answers of the students from Information Science, Audiovisual Communication, and Pedagogy degrees, who are more aware of the possible negative impact of technologies on their learning processes.

Finally, when approaching affinities between degrees, it should be put forward that the degrees that present greater similarity are Business Management and Administration and Tourism, followed by the pair Economy and Education, which is next to the group formed by Audiovisual Communication, Pedagogy, and Journalism. The degree in Information Science shows a different position, as it appears apart from the rest. This is understood because of the curricular profile of the degree, focused precisely on everything related to the information ecosystem. This fact highlights the singularity of Information Science students regarding the rest of the degrees, where, as mentioned before in the sample presentation, IL is addressed explicitly in a single subject (Audiovisual Communication and Journalism degrees) or unfortunately in none (Business Management and Administration, Tourism, Economy, Education, and Pedagogy degrees). On the other hand, in these degrees there is not a joint training with the academic libraries that favors the global acquisition of these competencies, in spite of the fact that, as Julien, Gross, and Latham state, the librarians can play a relevant role in the training of the student body for the acquisition of the skills in IL, which should be emphasized and made visible. ${ }^{34}$

The cluster arrangement is consistent with the differences shown in table 9. The results indicate that analyzing similarity data between degrees with MDS and cluster analysis provides complementary information that serves as a basis for discovering patterns of behavior. ${ }^{35}$

\section{Conclusions and Recommendations}

The reliability of the MOBILE-APPS questionnaire is consolidated after applying the instrument to a representative sample of social science students from eight disciplines (Audiovisual Communication, Information Science, Business Management and Administration, Economy, Education, Journalism, Pedagogy, and Tourism). Also, it was found that the factorial model resulting from the data analysis consolidates the stability of the instrument and guarantees its transferability.

It is well known that IL is undoubtedly one of the pillars of lifelong learning. But life has become largely digital, and IL takes on a central role in the conceptualization of digitalinformation literacy. Its importance is becoming increasingly evident, even urgent, and this will only increase in all areas of education, especially higher education. In this highly technological environment, it is important to remember, as proposed by James Elmborg in a pioneering study, ${ }^{36}$ that the basis lies in helping students to develop a critical consciousness toward information. And, in the digital and mobile context that surrounds us, it is also a priority to provide learners with the appropriate competencies to handle technology in a way that empowers them as citizens and, at the same time, as future professionals.

As an example for educational reflection, McGraw Hill Education recently detected that only 4 out of every 10 undergraduate students in the United States feel highly prepared for their future working lives. ${ }^{37}$ The figure puts a worrying gap on the table, as it is fewer than half. Awareness of the need to train students on a critical, transferable, and adaptable basis 
in a changing environment is an increasingly pressing challenge. Information literacy (from a metaliteracy view) can and will be a driving force, providing them with a much-needed ability to think critically, both for their academic years and for their future workplace. Today, and increasingly, every person should strengthen the critical thinking to learn to manage and contrast responsibly the enormous amount of information that surrounds us, to distinguish opinions from facts, to learn to consume and produce information in collaborative digital environments, always in an ethical manner, and to understand that all this is part of a necessarily life-long learning process. Therefore, we can claim IL as a key for the development of citizenship, education, and professional practice. ${ }^{38}$

This study confirms that the incorporation of mobile devices is proving to be an unstoppable reality that is increasingly in force in the field of higher education. However, both in the perception of the use of ICT and mobile technologies in the classroom and in the perception and understanding of IL (in its institutional and personal dimensions, and also regarding the $A C R L$ Framework threshold concepts) there are differences depending on the degree. There are also some differences according to the gender variable, which would be interesting to deepen in future studies. Furthermore, after applying a cluster analysis and a multidimensional scaling, the different profiles are verified according to the degrees analyzed. These results therefore may provide valuable insights for both educators and academic librarians to improve curriculum and instructional designs, as they underline the convenience of devising programs that address the specific needs of each cluster of disciplines.

The Horizon Report already highlights that university institutions should work to give a boost to information and digital literacies. ${ }^{39}$ Our research provides empirical information based on the belief that only by knowing the view of our students will it be possible to tailor IL instruction, paying attention to the aspects that need reinforcement and in a manner appropriate to contexts. For that purpose, it is relevant to promote studies that delve into disciplinary differences, ${ }^{40}$ as a way of being more precise in addressing particular training needs of specific learning communities on campus.

\section{Recommendations and Implications for Academic Libraries}

Therefore, after this diagnosis of the perception of a substantial sample of higher education students from various degrees in Social Sciences in terms of information literacy and the use of ICT and mobile technologies, two main lines of action may be proposed as recommendations to promote future work in this much-needed field, bearing in mind that what is key is to place students' needs at the center of any approach and educational endeavor:

- Encourage institutional measures: Work to promote the inclusion in curricula of specific IL subjects in degrees where these are not yet present, which, in the case of Spain, unfortunately are the vast majority.

- Support students through educational improvement actions: To develop complementary training programs in mobile information literacy, always from the critical perspective that is at the base of IL. To this end, it would be essential to take advantage of the alliances between the university faculty and the library staff and resources, in order to promote students' continuous training, also bearing in mind that: "Students are mobile and have expectations about the availability of university services while they are on the go. The Library and the University need to be cognizant of this and integrate mobile development into their strategic planning exercises." ${ }^{41}$ 
Indeed, the picture drawn by this research raises relevant implications and opportunities for academic librarians, encouraging their involvement in the ever-vibrant life cycle of IL in higher education. ${ }^{42}$

In this age of disinformation and fake news, and given the dynamic needs for academic training, fostering IL for the entire university community should be a priority. For this reason, many universities are promoting institutional plans to address the new education challenges posed by the current context, although most of them focus on the digital transformation of institutions. In any case, to meet societal demands in higher education, the academic library and the library staff have to be recognized as vital partners in the development of the strategy for the institution, a key asset for IL training, to make it sustainable and to support a real cultural change across the institution.

To be truly effective, IL training should be embedded in the curriculum. Unfortunately, in many university degrees in Spain, there is no training in IL within the curricula. For this reason, aiming to create more student-centered teaching and learning environments, the collaboration between faculty members and academic librarians may be even more crucial, precisely in situations such as the context of this study, in which most Social Sciences degrees do not have any information training subjects. Given the difficulty of carrying out reforms in the curricula, which in any case need time to be implemented, the library can become the epicenter for supporting training actions focused on the needs of each learning community, in its specific context. Thus, it is worth noting the enormous potential of academic librarians as support for teachers who want to promote IL in their students.

Regrettably, on many Spanish campuses today, undergraduate students, especially in the first years of their university studies, do not take full advantage of the library, its resources and educational possibilities and rarely turn to the assistance of librarians for their information needs or research work. Any IL initiative in higher education should raise awareness about the critical importance of the use of libraries, which are constantly recycling themselves to adapt to the demands of the information society and the needs it generates on their specific campuses.

In other words, greater collaboration and communication among faculty, librarians, and students needs to be fostered to improve students' IL skills, because "training developed jointly by faculty and librarians, in which each part shares from their experience and knowledge, as well as taking into account the views and opinions of students, could provide students a more well-rounded education. Collaboration could also ensure having information literacy programs that work for everyone, which would be a more positive and fruitful academic experience for all stakeholders." ${ }^{43}$

All in all, this study provides a snapshot of the perceptions of Social Sciences undergraduates and, for future studies, as a next step it will also be essential to examine the faculty's perceptions to compare possible divergences and analyze the generational gap. Also, followup studies could be conducted after the implementation of training initiatives, with support from the library, to examine how these perceptions might have evolved. This would make it possible to develop strategies and resources to improve the weaknesses that may be diagnosed, according to the diverse degrees' profiles, and contribute to the indispensable development of IL as a key focus in higher education. 


\section{Acknowledgments}

This research is part of the national R\&D project "Innovation and training in the information competencies of university teachers and students in the Social Sciences. Model for the development of programs in the mobile environment" (CSO2016-80147-R), funded by the Spanish Ministry of Economy, Industry and Competitiveness. The authors are deeply grateful to all the students who participated in this research. 


\section{APPENDIX. MOBILE-APPS Questionnaire}

Students' perception regarding the importance of using mobile technologies in the teaching-learning of information competencies

\begin{tabular}{|c|c|c|c|c|c|c|c|c|}
\hline \multirow[b]{2}{*}{ The informationally literate university... } & \multicolumn{5}{|c|}{$<-$ Strongly disagree } & \multicolumn{3}{|c|}{ Strongly agree-> } \\
\hline & & & & & & & & \\
\hline 1. Is the future of higher education & 1 & 2 & 3 & 4 & 5 & 6 & 7 & DK/NO \\
\hline \multicolumn{9}{|l|}{$\begin{array}{l}\text { 2. Promotes critical and reflective thinking in the education } \\
\text { community }\end{array}$} \\
\hline \multicolumn{9}{|l|}{ 3. Fosters lifelong learning } \\
\hline \multicolumn{9}{|l|}{ 4. Makes the teaching-learning process easier } \\
\hline \multicolumn{9}{|l|}{$\begin{array}{l}\text { 5. Assumes that teaching will be of an increasingly ubiquitous } \\
\text { or blended nature }\end{array}$} \\
\hline \multicolumn{9}{|l|}{ An informationally literate person is one who... } \\
\hline 6. Knows how to identify their information needs & 1 & 2 & 3 & 4 & 5 & 6 & 7 & $\mathrm{DK} / \mathrm{NO}$ \\
\hline \multicolumn{9}{|l|}{$\begin{array}{l}\text { 7. Understands and uses relevant and quality information } \\
\text { sources }\end{array}$} \\
\hline \multicolumn{9}{|l|}{$\begin{array}{l}\text { 8. Uses varied information resources (websites, databases, } \\
\text { eBooks, books, academic articles, etc.) efficiently and } \\
\text { effectively }\end{array}$} \\
\hline \multicolumn{9}{|l|}{ 9. Evaluates information sources in a critical manner } \\
\hline \multicolumn{9}{|l|}{ 10. Properly cites the information sources used } \\
\hline \multicolumn{9}{|l|}{$\begin{array}{l}\text { 11. Knows how to disseminate information in a rigorous and } \\
\text { appropriate manner }\end{array}$} \\
\hline \multicolumn{9}{|l|}{ Rate the following statements } \\
\hline $\begin{array}{l}\text { 12. Authority is constructed and contextual (i.e., The authority } \\
\text { of information depends on the recipients ' perception of the } \\
\text { authority concept itself and the setting in question). }\end{array}$ & 1 & 2 & 3 & 4 & 5 & 6 & 7 & DK/NO \\
\hline \multicolumn{9}{|l|}{ 13. Creating information is a process } \\
\hline \multicolumn{9}{|l|}{ 14. Information has value } \\
\hline \multicolumn{9}{|l|}{ 15. Research is a process of questioning } \\
\hline \multicolumn{9}{|l|}{ 16. Learning is a dialog } \\
\hline \multicolumn{9}{|l|}{ 17. The search for information requires a strategy } \\
\hline \multicolumn{9}{|l|}{ ICT and students } \\
\hline $\begin{array}{l}\text { 18. I usually take notes or search for information on mobile } \\
\text { devices (laptops, tablets, or smartphones) }\end{array}$ & 1 & 2 & 3 & 4 & 5 & 6 & 7 & DK/NO \\
\hline \multicolumn{9}{|l|}{$\begin{array}{l}\text { 19. I believe that I am able to access all the information I need } \\
\text { using ICTs and mobile devices }\end{array}$} \\
\hline \multicolumn{9}{|l|}{$\begin{array}{l}\text { 20. Instant access to information improves my critical thinking } \\
\text { skills when selecting verified information and documents }\end{array}$} \\
\hline \multicolumn{9}{|l|}{$\begin{array}{l}\text { 21.The use of ICTs helps lower the importance I give to citing } \\
\text { sources }\end{array}$} \\
\hline $\begin{array}{l}\text { 22. Mobile devices have contributed towards my being more } \\
\text { distracted in class }\end{array}$ & & & & & & & & \\
\hline
\end{tabular}




\section{Notes}

1. OECD, The Definition and Selection of Key Competencies (DeSeCo). Executive Summary, 2005, accessed February 6, 2020, www.oecd.org/pisa/35070367.pdf.

2. Bill Johnston and Sheila Webber, "Information Literacy in Higher Education: A Review and Case Study," Studies in Higher Education 28, no. 3 (2003): 335-52, https://doi.org/10.1080/03075070309295; Sheila Webber and Bill Johnston, "Working towards the Information Literate University," in Information Literacy: Recognising the Need, eds. Geoff Walton and Alison Pope (Oxford, UK: Chandos, 2006), 47-58.

3. Wan Ng, "Conceptualising mLearning Literacy," International Journal of Mobile and Blended Learning 5, no. 1 (2013): 1-20, https://doi.org/10.4018/jmbl.2013010101.

4. Association of College \& Research Libraries (ACRL), Framework for Information Literacy for Higher Education (2015), accessed February 6, 2020, www.ala.org/acrl/standards/ilframework.

5. ACRL, Framework; Thomas P. Mackey and Trudi E. Jacobson, "Reframing Information Literacy as a Metaliteracy," College \& Research Libraries 72, no. 1 (2011): 62-78, https://doi.org/10.5860/crl-76r1; Thomas P. Mackey and Trudi E. Jacobson, Metaliteracy: Reinventing Information Literacy to Empower Learners (Chicago, IL: Neal-Schuman, 2014).

6. CILIP Information Literacy Group, CILIP Definition of Information Literacy 2018, accessed February 6, 2020, https://infolit.org.uk/new-il-definition.

7. Eliana E. Gallardo Echenique et al., "Digital Competency in the Knowledge Society,” MERLOT: Journal of Online Learning and Teaching 11, no. 1 (2015): 1-16, accessed February 6, 2020, http://jolt.merlot.org/vol11no1/ Gallardo-Echenique_0315.pdf.

8. Jane Secker, "The Trouble with Terminology: Rehabilitating and Rethinking 'Digital Literacy'," in Digital Literacy Unpacked, eds. Katharine Reedy and Jo Parker (London, UK: Facet Publishing, 2017), 3-16, accessed February 6, 2020, http://openaccess.city.ac.uk/20546/; Marcus Leaning, "An Approach to Digital Literacy through the Integration of Media and Information Literacy," Media and Communication 7, no. 2 (2019): 4-13, http://dx.doi. org/10.17645/mac.v7i2.1931.

9. Secker, "The Trouble with Terminology."

10. ACRL, Framework, 2.

11. Rebecca Z. Kuglitsch, “Teaching for Transfer: Reconciling the Framework with Disciplinary Information Literacy," portal: Libraries and the Academy 15, no. 3 (2015): 457-70, https://doi.org/10.1353/pla.2015.0040.

12. Amanda L. Folk, "Drawing on Students' Funds of Knowledge: Using Identity and Lived Experience to Join the Conversation in Research Assignments," Journal of Information Literacy 12, no. 2 (2018): 44-59, https://doi. org/10.11645/12.2.2468.

13. Rachel E. Scott, "Transformative? Integrative? Troublesome? Undergraduate Honors Student Reflections on Information Literacy Threshold Concepts," Communications in Information Literacy 11, no. 2 (2017): 283-301, https://doi.org/10.15760/comminfolit.2017.11.2.3; Britt Foster, Matthew Doyle, and Mariya Yukhymenko, Student Perceptions of Information Literacy Skills (PILS) Using the ACRL's Framework for Information Literacy for Higher Education (2018), accessed February 6, 2020, https://repository.library.fresnostate.edu/bitstream/handle/10211.3/201211/_Perception\%20of\%20Information\%20Literacy\%20Skills\%20\%28PILS\%29.pdf?sequence=1.

14. Scott, "Transformative? Integrative? Troublesome?"

15. Foster, Doyle, and Yukhymenko, Student Perceptions of Information Literacy Skills (PILS); Matthew Doyle, Britt Foster, and Mariya Yukhymenko-Lescroart, "Initial Development of the Perception of Information Literacy Scale (PILS)," Communications in Information Literacy 13, no. 2 (2019): 205-27, https://doi.org/10.15760/comminfolit.2019.13.2.5.

16. Amy R. Hofer, Silvia Lin Hanick, and Lori Townsend, Transforming Information Literacy Instruction. Threshold Concepts in Theory and Practice (Santa Barbara, CA/Denver, CO: Libraries Unlimited, 2019).

17. Andrew Walsh, "Mobile Information Literacy: A Preliminary Outline of Information Behaviour in a Mobile Environment," Journal of Information Literacy 6, no. 2 (2012): 56-69, https://doi.org/10.11645/6.2.1696.

18. Ben Woodcock, Andrew Middleton, and Anne Nortcliffe, "Considering the Smartphone Learner: An Investigation into Student Interest in the Use of Personal Technology to Enhance their Learning," Student Engagement and Experience Journal 1, no. 1 (2012): 1-15.

19. Stefanie Havelka, "Mobile Information Literacy: Supporting Students' Research and Information Needs in a Mobile World," Internet Reference Services Quarterly 18, no. 3/4 (2013): 189-209, https://doi.org/10.1080/108753 01.2013.856366.

20. Hye-Young Yoon, “User Acceptance of Mobile Library Applications in Academic Libraries: An Application of the Technology Acceptance Model," Journal of Academic Librarianship 42, no. 6 (2016): 687-93, https://doi. org/10.1016/j.acalib.2016.08.003. 
21. J. Petrus Bosman and Sonja Strydom, "Mobile Technologies for Learning: Exploring Critical Mobile Learning Literacies as Enabler of Graduateness in a South African Research-Led University," British Journal of Educational Technology 47, no. 3 (2016): 510-19, https://doi.org/10.1111/bjet.12441.

22. Kimberly Mullins, “Research Plus ${ }^{\mathrm{TM}}$ Mobile App: Information Literacy 'On the Go,'” Reference Services Review 45, no. 1 (2017): 38-45, https://doi.org/10.1108/RSR-03-2016-0020.

23. Mostafa Al-Emran, Hatem M. Elsherif, and Khaled Shaalan, "Investigating Attitudes towards the Use of Mobile Learning in Higher Education," Computers in Human Behavior 56 (2016): 93-102, https://doi.org/10.1016/j. chb.2015.11.033.

24. Alice Schmidt Hanbidge, Tony Tin, and Nicole Sanderson, "Information Literacy Skills on the Go: Mobile Learning Innovation," Journal of Information Literacy 12, no. 1 (2018): 118-36, http://dx.doi.org/10.11645/12.1.2322.

25. Gwo-Jen Hwang et al., "A Long-term Experiment to Investigate the Relationships between High School Students' Perceptions of Mobile Learning and Peer Interaction and Higher-order Thinking Tendencies," Educational Technology Research and Development 66, no. 1 (2018): 75-93, https://doi.org/10.1007/s11423-017-9540-3.

26. Maria Pinto et al., "MOBILE-APPS Questionnaire: Developing and Validating a Scale to Measure the Attitudes and Perceptions of Undergraduate Students on Mobile Information Literacy," Journal of Librarianship and Information Science (2020), https://doi.org/10.1177/0961000620902260. On IL tools' validation, see also the works by Bojana Boh Podgornik et al., "Development, Testing, and Validation of an Information Literacy Test (ILT) for Higher Education," Journal of the Association for Information Science and Technology 67 (2016): 2420-36, https://doi. org/10.1002/asi.23586; and Nordin Hani Syazillah, K. Kiran, and G. Chowdhury, "Adaptation, translation, and validation of information literacy assessment instrument," Journal of the Association for Information Science and Technology 69, no. 8 (2018): 996-1006, https://doi.org/10.1002/asi.24023.

27. Jum C. Nunnally, Psychometric Theory, 2nd ed. (New York, NY: McGraw-Hill, 1978); Eunseong Cho and Seonghoon Kim, "Cronbach's Coefficient Alpha: Well Known but Poorly Understood," Organizational Research Methods 18, no. 2 (2015): 207-30, https://doi.org/10.1177/1094428114555994; Keith S. Taber, "The Use of Cronbach's Alpha When Developing and Reporting Research Instruments in Science Education," Research in Science Education 48, no. 6 (2018): 1273-96, https://doi.org/10.1007/s11165-016-9602-2.

28. Ton J. Cleophas and Aeilko Zwinderman, "Non-parametric Tests for Three or More Samples (Friedman and Kruskal-Wallis)," in Clinical Data Analysis on a Pocket Calculator (Cham, Switzerland: Springer, 2016), $193-97$.

29. Carl J. Huberty, E. Michael Jordan, and W. Christopher Brandt, "Cluster Analysis in Higher Education Research," in Higher Education: Handbook of Theory and Research, ed. John C. Smart (Dordrecht, Netherlands: Springer, 2005), 437-57.

30. Joseph Hair et al., Multivariate Data Analysis: A Global Perspective, 7th ed. (Upper Saddle River, NJ: Pearson Prentice Hall, 2010); Andy Field, Discovering Statistics Using IBM SPSS Statistics (Newcastle, UK: SAGE Publications, 2013).

31. Trevor Cox and Michael Cox, Multidimensional Scaling (London, UK: Chapman and Hall/CRC, 2000); Ingwer Borg and Patrick Groenen, "Modern Multidimensional Scaling: Theory and Applications," Journal of Educational Measurement 40, no. 3 (2003): 277-80, https://doi.org/10.1111/j.1745-3984.2003.tb01108.x.

32. Nicole A. Branch, "Illuminating Social Justice in the Framework: Transformative Methodology, Concept Mapping and Learning Outcomes Development for Critical Information Literacy," Communications in Information Literacy 13, no. 1 (2019): 4-22, https://doi.org/ 10.15760/comminfolit.2019.13.1.2.

33. Megan K. Foti and Jomayra Mendez, "Mobile Learning: How Students Use Mobile Devices to Support Learning," Journal of Literacy and Technology 15, no. 3 (2014): 58-78; Ahmet Naci Çoklar, Nihal Dulkadir Yaman, and Işil Kabakçi Yurdakul, "Information Literacy and Digital Nativity as Determinants of Online Information Search Strategies," Computers in Human Behavior 70 (2017): 1-9, https://doi.org/10.1016/j.chb.2016.12.050.

34. Heidi Julien, Melissa Gross, and Don Latham, "Survey of Information Literacy Instructional Practices in US Academic Libraries," College E Research Libraries 79, no. 2 (2018): 179-99, https://doi.org/10.5860/crl.79.2.179.

35. Stephen G. Sireci and Kurt F. Geisinger, "Analyzing Test Content Using Cluster Analysis and Multidimensional Scaling," Applied Psychological Measurement 16, no. 1 (1992): 17-31, https://doi.org/10.1177/014662169201600102.

36. James Elmborg, "Critical Information Literacy: Implications for Instructional Practice," Journal of Academic Librarianship 32, no. 2 (2006): 192-99, https://doi.org/10.1016/j.acalib.2005.12.004.

37. McGraw Hill Education, 2018 Future Workforce Survey, Spring 2018, accessed February 6, 2020, https://www. mheducation.com/future-workforce.html.

38. Information Literacy in the Workplace, ed. Marc Forster (London, UK: Facet, 2017); Informed Societies: Why Information Literacy Matters for Citizenship, Participation and Democracy, ed. Stéphane Goldstein (London, UK: Facet, 2020).

39. Bryan Alexander et al., EDUCAUSE Horizon Report: 2019 Higher Education Edition, accessed February 6, 2020, https://library.educause.edu/-/media/files/library/2019/4/2019horizonreport.pdf?la=en\&hash=C8E8D444A F372E705FA1BF9D4FF0DD4CC6F0FDD1\&hash=C8E8D444AF372E705FA1BF9D4FF0DD4CC6F0FDD1. 
40. Stefan Dreisiebner and Christian Schlögl, "Assessing Disciplinary Differences in Information Literacy Teaching Materials," Aslib Journal of Information Management 71, no. 3 (2019): 392-414, https://doi.org/10.1108/AJIM07-2018-0183; Maria Pinto, "Assessing Disciplinary Differences in Faculty Perceptions of Information Literacy Competencies," Aslib Journal of Information Management 68, no. 2 (2016): 227-47, https://doi.org/10.1108/AJIM-052015-0079; Maria Pinto and Dora Sales, "Uncovering Information Literacy's Disciplinary Differences through Students' Attitudes: An Empirical Study," Journal of Librarianship and Information Science 47, no. 3 (2015): 204-15, https://doi.org/10.1177/0961000614532675.

41. Sally Wilson and Graham McCarthy, "The Mobile University: From the Library to the Campus," Reference Services Review 38, no. 2 (2010): 214-32, 225.

42. Ada Ducas, Nicole Michaud-Oystryk, and Marie Speare, "Reinventing Ourselves: New and Emerging Roles of Academic Librarians in Canadian Research-Intensive Universities," College E Research Libraries 81, no. 1 (2020): 43-65, https://doi.org/10.5860/crl.81.1.43.

43. Anna Yevelson-Shorsher and Jenny Bronstein, "Three Perspectives on Information Literacy in Academia: Talking to Librarians, Faculty, and Students," College E Research Libraries 79, no. 4 (2018): 548, https://doi.org/10.5860/ crl.79.4.535. 